\title{
Trends in DDT and pyrethroid resistance in Anopheles gambiae s.s. populations from urban and agro-industrial settings in southern Cameroon
}

\author{
Philippe Nwane ${ }^{* 1,2}$, Josiane Etang1,3, Mouhamadou Chouaibou1,2, \\ Jean Claude Toto ${ }^{1}$, Clément Kerah-Hinzoumbé ${ }^{2}$, Rémy Mimpfoundi², \\ Herman Parfait Awono-Ambene ${ }^{1}$ and Frédéric Simard ${ }^{5}$
}

Address: ${ }^{1}$ Organisation de Coordination pour la lutte contre les Endémies en Afrique Centrale, Yaoundé, Cameroun, ${ }^{2}$ Université de Yaoundé I, Yaoundé, Cameroun, ${ }^{3}$ Faculty of Medicine and Pharmaceutical Sciences, University of Douala, Cameroun, ${ }^{4}$ Programme National de Lutte contre le Paludisme, N'Djamena, Tchad and ${ }^{5}$ Institut de Recherche pour le Développement (IRD), UR016, Bobo-Dioulasso, Burkina Faso

Email: Philippe Nwane* - philino07@yahoo.fr; Josiane Etang - josyet@yahoo.fr; Mouhamadou Chouaibou - ms_chouaibou@yahoo.fr; Jean Claude Toto - jctotofr@yahoo.fr; Clément Kerah-Hinzoumbé - kerah_clement@yahoo.fr;

Rémy Mimpfoundi - remymimpfoundi@yahoo.fr; Herman Parfait Awono-Ambene - hpaawono@yahoo.fr;

Frédéric Simard - frederic.simard@ird.fr

* Corresponding author

Published: 30 September 2009

BMC Infectious Diseases 2009, 9:163 doi:10.1186/1471-2334-9-163
Received: 2 June 2009

Accepted: 30 September 2009

This article is available from: http://www.biomedcentral.com//47/-2334/9//63

(c) 2009 Nwane et al; licensee BioMed Central Ltd.

This is an Open Access article distributed under the terms of the Creative Commons Attribution License (http://creativecommons.org/licenses/by/2.0), which permits unrestricted use, distribution, and reproduction in any medium, provided the original work is properly cited.

\begin{abstract}
Background: Pyrethroid insecticides are widely used for insect pest control in Cameroon. In certain insect species, particularly the malaria vector Anopheles gambiae, resistance to this class of insecticides is a source of great concern and needs to be monitored in order to sustain the efficacy of vector control operations in the fields. This study highlights trends in DDT and pyrethroid resistance in wild An. gambiae populations from South Cameroon.
\end{abstract}

Methods: Mosquitoes were collected between $200 \mathrm{I}$ and 2007 in four sites in South Cameroon, where insecticides are used for agricultural or personal protection purposes. Insecticide use was documented in each site by interviewing residents. Batches of 2-4 days old adult female mosquitoes reared from larval collections were tested for susceptibility to DDT, permethrin and deltamethrin using standard WHO procedures. Control, dead and survivors mosquitoes from bioassays were identified by PCRRFLP and characterized for the kdr mutations using either the AS-PCR or the HOLA method.

Results: Four chemical insecticide groups were cited in the study sites: organochlorines, organophosphates, carbamates and pyrethroids. These chemicals were used for personal, crop or wood protection. In the four An. gambiae populations tested, significant variation in resistance levels, molecular forms composition and $k d r$ frequencies were recorded in the time span of the study. Increases in DDT and pyrethroid resistance, as observed in most areas, were generally associated with an increase in the relative frequency of the $S$ molecular form carrying the $k d r$ mutations at higher frequencies. In Mangoum, however, where only the $\mathrm{S}$ form was present, a significant increase in the frequency of $k d r$ alleles between 2003 to 2007 diverged with a decrease of the level of resistance to DDT and pyrethroids. Analyses of the $k d r$ frequencies in dead and surviving mosquitoes showed partial correlation between the kdr genotypes and resistance phenotypes, suggesting that the kdr mechanism may act with certain cofactors to be identified.

Conclusion: These results demonstrate the ongoing spread of $k d r$ alleles in An. gambiae in Central Africa. The rapid evolution of insecticide resistance in this highly dynamic and genetically polymorphic species remains a challenge for its control. 


\section{Background}

Agriculture and timber production are the main components of the economical activities in most equatorial African countries. These economic activities require intensive use of pesticides including insecticides belonging to the four main chemical groups used in public health: organochlorines, carbamates, organophosphates and pyrethroids. In Cameroon, organochlorines such as DDT have been used extensively for both vector control and agricultural purposes in the southern areas of the country, especially during the 1950s malaria eradication campaign [1$3]$. However, these compounds have progressively been replaced by alternative more specific and less toxic chemicals, in part because of the emergence of insecticide resistance in the target species $[1,4]$. Nowadays, pyrethroids are largely recommended because of their high effectiveness and strong excito-repellent effect on insects, as well as low mammalian toxicity [5-8]. However, the extensive exposure of insect pests to these insecticides has already selected resistance in wild insect populations $[9,10]$. To date, more than 500 species of insects and mites have been reported to develop resistance to about 300 insecticide compounds [11-13]. Among these species, 56\% are crop pests, $39 \%$ are arthropods of medical or veterinary importance and 5\% are beneficial species [14].

The emergence of insect resistance to insecticides may decrease crop productivity [15] or reduce the effectiveness of insecticide treated nets or indoor residual spraying $[13,16]$. Resistance management is therefore a major challenge for vector control programmes in countries where vector-borne diseases are endemic and subsistence remains a burden to the communities. Malaria is the most devastating of all vector-borne diseases; it impedes on economic development not only by causing premature death but also through lost/diminished productivity, absenteeism, huge medical cost, and negative impact on fertility, population growth, and country's savings and investments [17].

Several insecticide resistance mechanisms have been reported in different classes of insects of medical and economic importance, particularly among major malaria vectors belonging to the Anopheles gambiae complex [18-21]. These mechanisms include enhanced detoxification of insecticides through increased enzymatic activities of esterases, gluthatione S-transferases and cytochrome $\mathrm{P}_{450}$ monooxygenases, mainly due to their overproduction as a result of gene amplification $[22,23]$ and/or gene regulation [24-26]. Point mutations at the target sites of insecticides, decreasing the affinity of the insecticide to its receptor, constitute the second major and most widespread mechanism by which insects are able to resist insecticides [27]. Two mutations at amino acid position 1014 of the voltage-gated sodium channel, changing either a Leucine residue to a Phenylalanine (L1014F) [28], or a Leucine to a Serine (L1014S) [29] have been identified in Anopheles gambiae and confer knockdown resistance $(k d r)$ to DDT and pyrethroid insecticides. On the other hand, organophosphates and carbamates are acetylcholinesterase inhibitors; structural changes in this enzyme in Drosophila melanogaster, Musca domestica and An. gambiae were reported to cause resistance to these insecticides [30-33].

In Cameroon, cross-sectional surveys of An. gambiae s.l. susceptibility to insecticides have been carried out since 1997. Metabolic resistance was suspected in some An. gambiae populations in 2003 and confirmed in 2007 $[34,35]$. More recently, the presence of both $k d r$ mutations and their relationship with phenotypic resistance to pyrethroids and DDT were reported in Cameroon [36,37]. Here, we explore trends in insecticide resistance in wild An. gambiae populations from Southern Cameroon, through the longitudinal follow-up of insecticide susceptibility levels in four sites where insecticides are used extensively for agricultural or personal protection purposes.

\section{Methods \\ Study sites and insecticide usage}

The study was conducted in 4 localities (Figure 1) of Southern Cameroon that are characterized by high insecticide usage for agro-industry or personal protection: (1) Ipono district $\left(2^{\circ} 22^{\prime} \mathrm{N}, 9^{\circ} 50^{\prime} \mathrm{E}\right)$, an area of intensive forest exploitation and timber storage, with agricultural activities limited to the households' supplies, (2) Bonanloka district $\left(4^{\circ} 03^{\prime} \mathrm{N}, 9^{\circ} 43^{\prime} \mathrm{E}\right)$, a highly urbanized area in the centre of Douala, the major economic city in Cameroon, where inhabitants use insecticides against arthropod nuisance, (3) Nkolondom district $\left(3^{\circ} 51^{\prime} \mathrm{N}\right.$, $\left.11^{\circ} 30^{\prime} \mathrm{E}\right)$, a market gardening area located in the outskirts of Yaoundé, the capital city of Cameroon, and (4) Mangoum district $\left(5^{\circ} 31^{\prime} \mathrm{N}, 10^{\circ} 37^{\prime} \mathrm{E}\right)$, a locality with extensive manual and mechanized agricultural settings producing spices, vegetables and cereals. These sites are among the places in Cameroon where agricultural and forest exploitation practices are sustained by pesticide application.

These localities are geographically located in the southern region of the country under the equatorial climate, with average yearly rainfall above $1,500 \mathrm{~mm}$ spread out over 4 seasons: 2 dry seasons (December-February and JulyAugust) and 2 rainy seasons (March-June and SeptemberNovember). However, noticeable variations of these climatic trends are observed in Mangoum located in the western mountain grassland characterized by one dry season between November and February, and one rainy season between March and October [38]. Mosquito larvae 


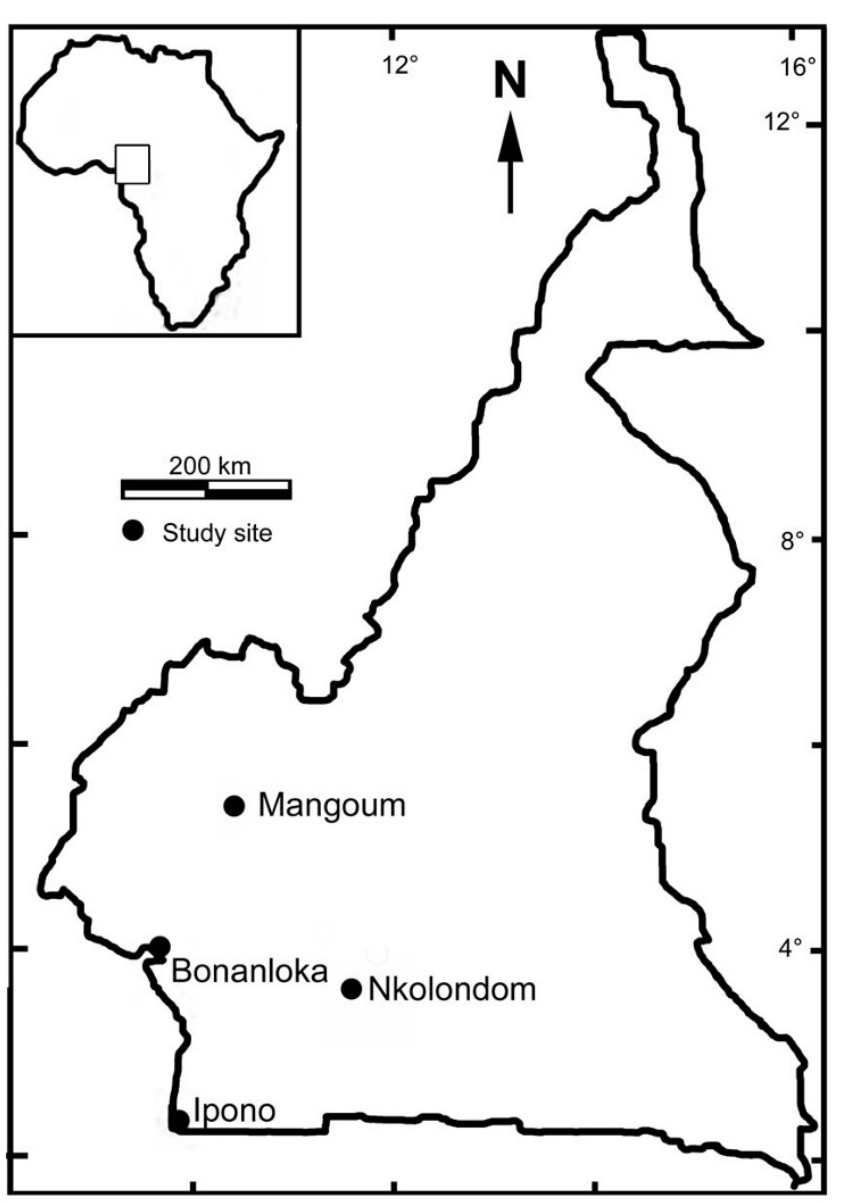

Figure I

Map of Cameroon showing study sites.

were collected during the rainy seasons in 2001, 2003, 2005 and 2007.

During mosquitoes sampling in 2003, a qualitative survey was conducted in each site with the aim to document the most widely used insecticide compounds and agricultural practices. Data concerning insecticide usage in public health, personal protection and agro-industry were collected by filling a standardized questionnaire. Questions asked to local inhabitants, gardeners or owners of timber yards were mainly focused on: (1) insecticides used (trade names/active ingredients), (2) cultivated crops and their treatment cycles, (3) operational dosages during crop treatments and (4) exploited surface for plant farming or wood storage.

\section{Mosquito collections and bioassays}

Anopheline larvae were collected from a wide range of breeding sites, representative of the diversity of the mosquito population in each study site. Larvae were collected from puddles, flooded furrows, shallow wells, tire tracks, ponds and marshes. In each location, larval collections were performed in at least 20 breeding sites in which an average of 30 larvae (all instars) per breeding site were collected and reared locally to adults, and fed with a $10 \%$ sucrose solution. Upon emergence, mosquitoes were sexed and morphologically identified using morphological identification keys $[39,40]$. Only females An. gambiae s.l. were used for insecticide resistance monitoring. Susceptibility tests were carried out using WHO insecticide susceptibility test-kits and standard protocol for adults [41]. Impregnated filter papers (4\% DDT, 0.75\% permethrin and $0.05 \%$ deltamethrin) were provided by the Vector Control and Research Unit, University Sains Malaysia (Penang, Malaysia). Bioassays were performed at a temperature ranging from 25 to $28^{\circ} \mathrm{C}$ on 2 -4-days old females. For each test, 80-100 mosquitoes separated into 4 batches were exposed to impregnated filter papers, while a batch of 20-25 mosquitoes served as control. The number of knockdown mosquitoes was recorded at $5 \mathrm{~min}$ intervals during $1 \mathrm{~h}$ exposure and mortality was determined $24 \mathrm{~h}$ post-exposure. At each sampling period, bioassays were concomitantly carried out with the Kisumu strain of An. gambiae maintained in the Laboratoire de Recherche sur le Paludisme at OCEAC (Yaounde, Cameroon) and used as the reference susceptible strain. Assayed samples were preserved individually on dessiccant (silica gel) and stored at $-20^{\circ} \mathrm{C}$ for further analysis.

\section{Molecular identification and kdr genotyping}

Upon completion of the susceptibility tests and recording of the individual phenotypes, random samples of mosquitoes from bioassays batches at each study period e.g. control, dead and surviving specimens were subjected to DNA extraction [42]. Specimens were identified to species and molecular form by PCR-RFLP [43]. Their genotype at the $k d r$ locus was determined using either the Allele-Specific PCR (AS-PCR) [28] in samples collected in 2001 and 2003, or the Hot Oligonucleotide Ligation Assay (HOLA) [44] in samples collected in 2005 and 2007.

\section{Data analysis}

Insecticide susceptibility data were analysed according to WHO criteria [41]: samples were defined as resistant if they showed less than $80 \%$ mortality; a mortality rate between $80-98 \%$ suggested reduced susceptibility but resistance needs to be confirmed, while mortality rates greater than $98 \%$ were indicative of complete susceptibility. The knockdown times for 50 and $95 \%$ of tested mosquitoes $\left(\mathrm{KdT}_{50}\right.$ and $\left.\mathrm{KdT}_{95}\right)$ were estimated using a logtime probit model [45]. The $\mathrm{KdT}_{50}$ recorded from fieldcollected mosquitoes were compared with that of the An. gambiae Kisumu reference susceptible strain by estimates of $\mathrm{KdT}_{50}$ ratios (RR). Chi-square tests were used to compare the prevalence of $\mathrm{M}$ and $\mathrm{S}$ molecular forms of $A n$. gambiae between the different study periods. 


\section{Results Insecticide usage in study sites}

More than 30 forms were filled in each study site, except in the Ipono timber yards where only one form was filled because chemical insecticides were not used for another purposes in this study area. Chemicals in use during year 2003 differed from one site to another. Table 1 summarises data collected from surveys conducted in the agricultural settings of Nkolondom and Mangoum. In these sites organophosphates (dimethoate, diazinon, chlorpyrifosethyl) and pyrethroids (lambda-cyhalothrin, cypermethrin and deltamethrin) were commonly used for crop protection. In addition, organochlorines (endosulfan and fipronil) and carbamates (carbofuran, methyl-parathion) were also used, especially in Nkolondom. However, large variability among gardeners in application dosages, the crop treatment cycles and the amounts of active ingredients used in these agricultural settings prevented quantitative analysis of the data.

In Bonanloka (urban area), bomb sprays and coils containing pyrethroid insecticides with cyfluthrin, deltamethrin, lambda-cyhalothrin as common active ingredients, were mainly used for personal protection. In the timber yard in Ipono, pyrethroids (bifenthrin and cypermethrin) and organochlorines (lindane) were used in insecticidefungicide mixtures to protect timber against xylophagous insects.

\section{Susceptibility to insecticides}

Throughout the assays, the Kisumu strain of An. gambiae displayed mortality rates above $99 \%$ for the 3 insecticides tested and no significant variation was observed in knockdown times during the study periods. The $\mathrm{kdT}_{50}$ values were approximately $19.0 ; 9.5$ and 8.5 minutes respectively for DDT, deltamethrin and permethrin. The corresponding $\mathrm{kdT}_{95}$ values were around 30, 25 and 15 minutes. In control groups of the Kisumu strain as well as that of the wild An. gambiae populations (unexposed mosquitoes) mortality rates 24 hours post-exposure were always below $5 \%$. Mortality rates in field mosquito populations are shown in Figure 2 and their respective $\mathrm{kdT}_{50}$ and $\mathrm{kdT}_{95}$ are given in Table 2. Overall, the four An. gambiae populations showed different levels of resistance to the three insecticides from one year to another. In most cases, resistance was associated with an increase of knockdown times compared with the Kisumu susceptible strain, with a $\mathrm{kdT}_{50}$ ratio higher than 2 (Table 2 ).

In the Ipono and Nkolondom populations, an increase of resistance to DDT and pyrethroids was observed from 2003 to 2007, as shown by an increase of knockdown times and a significant decrease in mortality $(\mathrm{p}<0,05)$, particularly in the Ipono population (Table 2, Figure 2). Conversely, a decrease of resistance to DDT and pyre- throids was noted in the Mangoum population from 2003 to 2007; this decrease was mostly associated with significant increase of mortality rates $(\mathrm{p}<0.05)$ in 2007 (Figure 2 ), although the knockdown times were slightly elevated. In Bonanloka, variations in resistance levels to DDT and pyrethroids were noted across the three surveys. DDT resistance was highest in 2005, whereas full susceptibility to pyrethroids was observed at this time. Reduced susceptibility to pyrethroids was observed in 2001 and 2007, however.

\section{Mosquito species, molecular forms and kdr frequencies}

Samples of 40-50 specimens randomly drawn from control groups used for the susceptibility tests in each study site and period were identified molecularly to species and molecular form, and their genotype at the $k d r$ locus was determined (Table 3). All mosquitoes tested belonged to the An. gambiae s.s species. The $\mathrm{M}$ and $\mathrm{S}$ molecular forms were found together in Ipono, Nkolondom and Bonanloka samples. The relative frequency of the $\mathrm{M}$ form which was $100 \%$ at Bonanloka in 2001 and 60.5\% at Nkolondom in 2003 dropped to $58 \%$ and $4 \%$ in 2007, respectively $(\mathrm{p}<0.0001)$. On the other hand, no significant difference was seen in the relative frequencies of both forms in Ipono between collections conducted in 2003 and $2007\left(\chi^{2}=0.17, p=0.68\right)$. In Mangoum, only the $S$ molecular form was found throughout the 2 study periods.

Both L1014F and L1014S $k d r$ mutations were observed in three of the four An. gambiae populations tested, except in Bonanloka where only the L1014F mutation was recorded. Both mutations were found in individuals of the $S$ molecular form while only the L1014F mutation was found in the $\mathrm{M}$ form, although at low frequencies $(\mathrm{f}<0.2$, Table 3) and in samples collected in 2007 only. In the three localities where the L1014S was detected in the S form, its frequency did not differ significantly between 2005 and 2007 ( $p$ > 0.07). However, a significant increase in the frequency of the L1014F mutation was detected in most of the S form populations between 2003 and 2007, especially in Nkolondom, where it rose from 0\% in 2003 to $92 \%$ in 2007 ( $\mathrm{p}<0.0001)$.

\section{Resistance phenotype and $\mathrm{kdr}$ genotypes in $M$ and $S$ molecular forms from Ipono}

To explore the distribution of resistance phenotypes and $k d r$ genotypes within and between molecular forms of $A n$. gambiae, we further analysed the samples from Ipono assayed in 2007, because of presence of both $M$ and $S$ molecular forms, and of both L1014F and L1014S $k d r$ mutations in this site. A total of 214 An. gambiae s.s. specimens, randomly selected from control, dead or survivors to susceptibility tests (20-65 specimens per test) were successfully analysed. Among these mosquitoes, 46 (21.5\%) 
Table I: Insecticide usage in agricultural settings

\begin{tabular}{|c|c|c|c|c|}
\hline Study site & Trade name (concentration) & Active ingredient & $\begin{array}{l}\text { Class of insecticide and } \\
\text { usage frequency }(\%)\end{array}$ & Cultivated crops \\
\hline \multirow[t]{8}{*}{ Nkolondom } & Bastion $(100 \mathrm{~g} / \mathrm{kg})$ & Carbofuran & Carbamates (33) & Cabbage, parsley* \\
\hline & Penncap.M (240 g/l), Sevin $(850 \mathrm{~g} / \mathrm{kg}$ & Methyl-parathion & & Celery*, lettuce*, \\
\hline & Callidim (400 g/l) Cyperdim (200 g/l) & Dimethoate & Organophosphorous (22) & Cabbage, \\
\hline & Basudine $(600 \mathrm{~g} / \mathrm{l})$ & Diazinon & & Pepper* \\
\hline & $\begin{array}{l}\text { Thionex } \\
\text { (500 g/l; } 350 \mathrm{~g} / \mathrm{l}) \text {, Thiodan }(250 \mathrm{~g} / \mathrm{l} 350 \mathrm{~g} / \mathrm{l})\end{array}$ & Endosulfan & Organochlorines (20) & Tomato, spinach* \\
\hline & Cypercal (12 g/l; $50 \mathrm{~g} / \mathrm{l} ; 100 \mathrm{~g} / \mathrm{l})$ & Cypermethrin & Pyrethroid (25) & $\begin{array}{l}\text { Celery*, tomato, green bean, } \\
\text { courgette, basil* }\end{array}$ \\
\hline & Décis (I2,5 g/l; $25 \mathrm{~g} / \mathrm{l} ; 60 \mathrm{~g} / \mathrm{l})$ & Deltamethrin & & Eggplant \\
\hline & Karate $(2,5 \% ; 5 \mathrm{~g} / \mathrm{l} ; 45 \mathrm{~g} / \mathrm{l})$ & Lambdacyhalothrin & & Tomato, ginger \\
\hline \multirow[t]{7}{*}{ Mangoum } & Thiodan (250 g/l; $350 \mathrm{~g} / \mathrm{l})$ & Endosulfan & Organochlorines (8) & Tomato* \\
\hline & Regent $(50 \mathrm{~g} / \mathrm{l})$ & Fipronil & & Cabbage* \\
\hline & $\begin{array}{l}\text { Callidim }(400 \mathrm{~g} / \mathrm{l}) \text {, Cyperdim }(200 \mathrm{~g} / \mathrm{l}) \text {, } \\
\text { Dimezyl }(400 \mathrm{~g} / \mathrm{l}) \text {, Planthoate }(400 \mathrm{~g} / \mathrm{l})\end{array}$ & Dimethoate & Organophosphorous (49) & $\begin{array}{l}\text { Cabbage*, bean, melon*, } \\
\text { watermelon*, tomato* lettuce, } \\
\text { nightshade* }\end{array}$ \\
\hline & Dursban (600 g/l), Pyriforce (600 g/l) & Chlorpyrifos-ethyl & & Corn \\
\hline & Pilori ( $15 \mathrm{~g} / \mathrm{l})$ & Lambdacyhalothrin & Pyrethroids (43) & Leek$^{*}$, carrot \\
\hline & Decis $(25 \mathrm{~g} / 1 ; 60 \mathrm{~g} / \mathrm{l} ; 12,5 \mathrm{~g} / \mathrm{l})$ & Deltamethrin & & Green bean \\
\hline & $\begin{array}{l}\text { Méteor }(400 \mathrm{~g} / \mathrm{l}) \text {, Cigogne }(50 \mathrm{~g} / \mathrm{l} ; 200 \mathrm{~g} / \mathrm{l}) \text {, } \\
\text { Cypercal }(12 \mathrm{~g} / \mathrm{l} ; 50 \mathrm{~g} / \mathrm{l} ; \mathrm{l} 100 \mathrm{~g} / \mathrm{l}) \text {, } \\
\text { Cyperplant }(100 \mathrm{~g} / \mathrm{l}) \text {, Cythrine }(25 \mathrm{~g} / \mathrm{l})\end{array}$ & Cypermethrin & & $\begin{array}{l}\text { Green bean, corn, tomato*, } \\
\text { carrot, leek*, nightshade*, potato }\end{array}$ \\
\hline
\end{tabular}

*: main cultivated crop

were $\mathrm{M}$ form and 168 (78.5\%) were S form (Table 4). No $\mathrm{M}$ form mosquito was identified within the group of survivors to insecticide exposure, suggesting complete susceptibility to the three compounds. Some dead specimens carried the L1014F allele at the heterozygous or homozygous state.

Among the 168 individuals of the $\mathrm{S}$ form, $26.8 \%$ belonged to control, $32.7 \%$ to dead and $40.5 \%$ to survivor samples. The two $k d r$ mutations were present in control, dead or survivor mosquitoes, with a considerable number of homozygote (L1014F/L1014F) and heterozygote (L1014F/L1014S) individuals in each of the three mosquito classes. All possible genotype combinations were observed in the control and dead mosquitoes, whereas only three genotypes were recorded in surviving mosquitoes, most of which were either double heterozygotes (L1014F/L1014S) or homozygotes for the "West African" $k d r$ mutation (L1014F/L1014F). No significant difference was seen in the frequency of the L1014S allele between dead and survivors to susceptibility tests, except with DDT where the frequency was lower in survivors $(\mathrm{p}<0.001)$. The frequency of L1014F allele was significantly higher in mosquitoes surviving to DDT and permethrin (0.86-0.96) than in dead mosquitoes $(0.41-0.50, \mathrm{P}<0.001)$. On the other hand, no significant difference was seen in L1014F frequency between dead and survivors to deltamethrin ( $P$ $=0.34)$. Overall, the frequencies of L1014F allele were higher in survivors than in the two other classes of mosquitoes.

\section{Discussion}

The survey on insecticide usage provided evidence for intensive use of chemical insecticides both for agro-industry and for personal protection in South Cameroon. It is consistent with observations made by Akogbéto and colleagues [46] that the choice and usage of chemical compounds depends on cultivated crops and specification of devastating insects.

Susceptibility data presented above confirmed that wild An. gambiae s.s. from the study area show reduced susceptibility to DDT and pyrethroids [34,36,47]. The level of resistance however, varies from one year to another, according to the proportion of the resistant $S$ form in the populations where the two molecular forms of An. gambiae were found together, especially in Nkolondom. In addition, the frequency of both $k d r$ alleles increased in time within the $S$ form in all sites where it was found. These results testify that the spread of the $k d r$ alleles is an ongoing process in An. gambiae mosquito populations from Cameroon [36], as well as elsewhere in Central Africa $[48,49]$.

The presence of the $k d r$ mutations in the malaria vector An. gambiae has been monitored using a variety of molecular techniques [50]. In this study, molecular detection of East and West $k d r$ genotypes were conducted using two PCR methods differing in their performance. Although the protocol assay used in 2003 [28] could not detected the 1014S allele, data collected in 2005 and 2007 using 
:4\%DDT $\square: 0.05 \%$ Deltamethrin $\square: 0.75 \%$ Permethrin
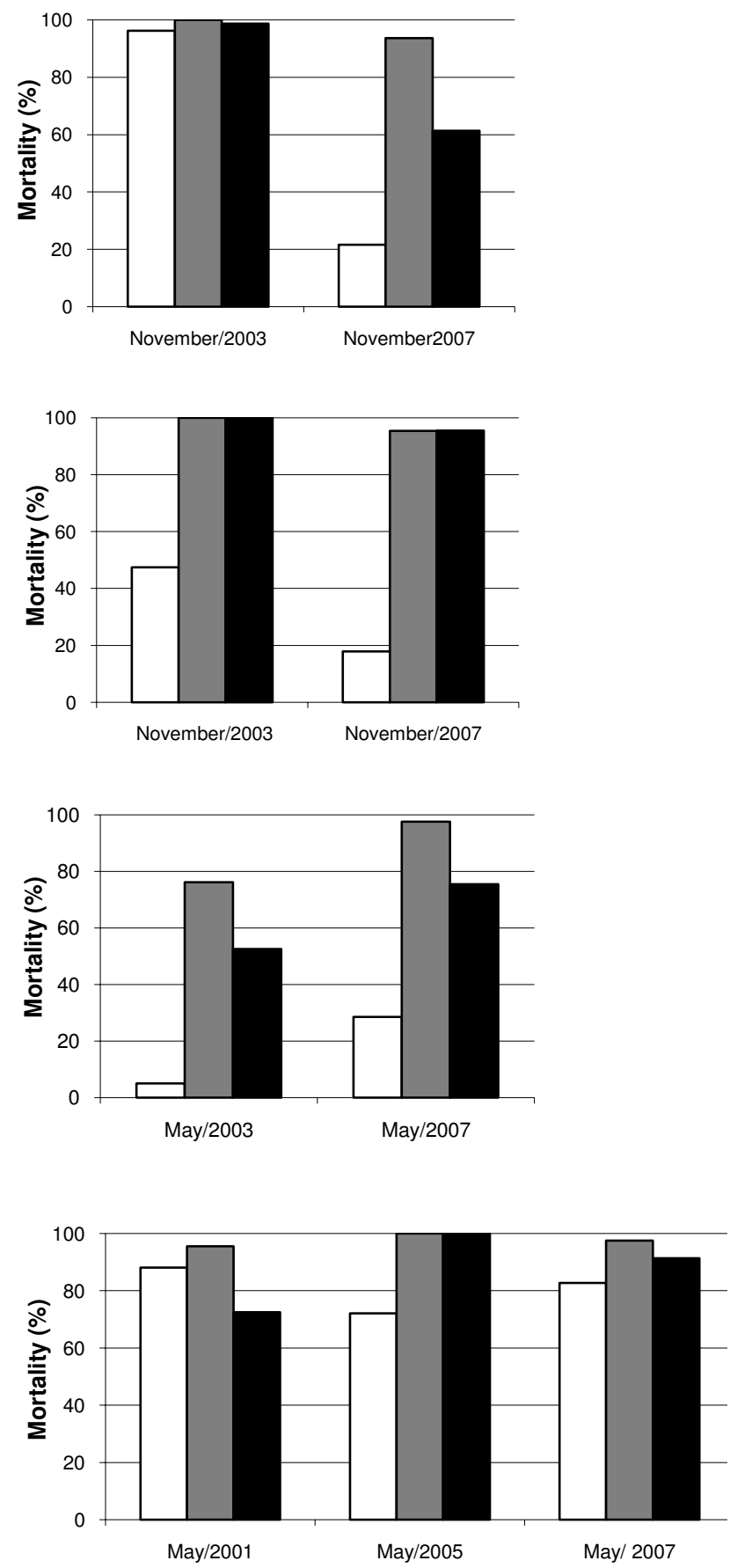

Figure 2

Mortality of Anopheles gambiae 24-hours post one-hour exposure to insecticide-impregnated papers at each study period. (A): Ipono, (B): Nkolondom, (C): Mangoum, (D): Bonanloka. 
Table 2: Knockdown time (kdT) for $\mathbf{5 0 \%}$ and $\mathbf{9 5 \%}$ of tested Anopheles gambiae s.l populations

\begin{tabular}{|c|c|c|c|c|c|c|c|}
\hline Site & Insecticide & Period & $\mathbf{N}$ & $\mathrm{kdT}_{50}\left[\mathrm{Cl}_{95}\right](\mathrm{min})$ & $\mathrm{kdT}_{95}\left[\mathrm{Cl}_{95}\right](\mathrm{min})$ & $\mathbf{R R}$ & Resistant status \\
\hline \multirow[t]{6}{*}{ Ipono } & 4\%DDT & Nov/2003 & 80 & $28.1[22.4-31.9]$ & $50.8[45.0-62.7]$ & 1.4 & RC \\
\hline & $0.05 \%$ Deltamethrin & & 79 & $8.3[5.4-10.9]$ & $24.0[18.1-38.9]$ & 0.8 & $\mathrm{~S}$ \\
\hline & 0.75\%Permethrin & & 79 & $11.5[10.2-12.8]$ & $44.3[39.2-51.2]$ & 1.3 & $S$ \\
\hline & $4 \% D D T$ & Nov/2007 & 87 & $>60$ & $>60$ & $>3$ & $\mathrm{R}$ \\
\hline & 0.05\%Deltamethrin & & 95 & | $3.7[|2.7-| 4.7]$ & 34.1 [31.3-37.4] & 1.4 & $\mathrm{RC}$ \\
\hline & 0.75\%Permethrin & & 88 & $37.3[34.1-40.6]$ & $>60$ & 4.1 & $\mathrm{R}$ \\
\hline \multirow[t]{6}{*}{ Nkolondom } & 4\%DDT & Nov/2003 & 80 & $>60$ & $>60$ & $>3$ & $\mathrm{R}$ \\
\hline & $0.05 \%$ Deltamethrin & & 89 & $12.2[3.7-18.8]$ & $42.8[32.7-61.0]$ & 1.2 & $S$ \\
\hline & 0.75\%Permethrin & & 86 & $12.6[9.6-\mid 5.4]$ & $47.1[37.3-67.4]$ & $\mathrm{I} .4$ & $S$ \\
\hline & $4 \% \mathrm{DDT}$ & Nov/2007 & 84 & $>60$ & $>60$ & $>3$ & $\mathrm{R}$ \\
\hline & 0.05\%Deltamethrin & & 89 & $20.1[17.1-22.8]$ & 45.8 [39. I-58.4] & 2.1 & $\mathrm{RC}$ \\
\hline & $0.75 \%$ Permethrin & & 83 & $40.2[37.6-42.8]$ & $>60$ & 4.5 & $\mathrm{RC}$ \\
\hline \multirow{6}{*}{ Mangoum } & $4 \% \mathrm{DDT}$ & May/2003 & 80 & $>60$ & $>60$ & $>3$ & $\mathrm{R}$ \\
\hline & 0.05\%Deltamethrin & & 84 & $24.1[22.4-25.1]$ & $39.2[37.1-42.0]$ & 2.5 & $\mathrm{R}$ \\
\hline & 0.75\%Permethrin & & 80 & $57.4[52.3-68.0]$ & $>60$ & 6.6 & $\mathrm{R}$ \\
\hline & $4 \% D D T$ & May/2007 & 91 & $>60$ & $>60$ & $>3$ & $\mathrm{R}$ \\
\hline & $0.05 \%$ Deltamethrin & & 84 & $19.4[16.4-22.0]$ & $48.3[41.8-59.1]$ & 2.0 & $\mathrm{RC}$ \\
\hline & $0.75 \%$ Permethrin & & 106 & $54.2[51.9-57.1]$ & $>60$ & 6.1 & $\mathrm{R}$ \\
\hline \multirow[t]{9}{*}{ Bonanloka } & $4 \% \mathrm{DDT}$ & May/200I & 80 & $49.3[41.8-58.7]$ & $>60$ & 2.6 & $\mathrm{RC}$ \\
\hline & 0.05\%Deltamethrin & & 86 & $22.4[21.2-23.7]$ & $34.8[31.2-39.0]$ & 2.4 & RC \\
\hline & $0.75 \%$ Permethrin & & 91 & $16.3[14.9-17.7]$ & $25.7[22.4-29.6]$ & 1.7 & $\mathrm{R}$ \\
\hline & $4 \% D D T$ & May/2005 & 80 & $51.6[41.9-54.0]$ & $>60$ & 2.7 & $\mathrm{R}$ \\
\hline & 0.05\%Deltamethrin & & 83 & $8.3[7.6-9.1]$ & $18.6[|6.8-2| .1]$ & 0.8 & $S$ \\
\hline & $0.75 \%$ Permethrin & & 85 & $6.2[3.6-8.5]$ & $23.8[18.0-37.2]$ & 0.7 & $S$ \\
\hline & $4 \% D D T$ & May/2007 & 87 & $37.9[36.5-39.5]$ & $>60$ & 1.9 & $\mathrm{RC}$ \\
\hline & 0.05\%Deltamethrin & & 84 & $12.8[10.6-14.6]$ & $24.1[20.4-31.6]$ & 1.3 & $\mathrm{RC}$ \\
\hline & 0.75\%Permethrin & & 88 & $15.2[13.2-17.1]$ & $35.3[30.7-42.6]$ & 1.7 & $\mathrm{RC}$ \\
\hline
\end{tabular}

$\mathrm{N}$ : sample size; $\mathrm{kdT}_{50}$ : knockdown time for $50 \%$ mosquitoes; $\mathrm{kdT}_{95}$ : knockdown time for $95 \%$ mosquitoes; $\mathrm{Cl}_{95}$ : confidence interval at $95 \%$; min: minutes; RR: resistance ratio ( $\mathrm{kdT}_{50}$ of the tested population/kdT ${ }_{50}$ of the Kisumu strain); S: susceptible; RC: resistance to be confirmed; R: resistant; Nov: November.

the protocol described by Lynd and colleagues [44] demonstrate the rapid invasion of the $k d r$ mutation in the studied An. gambiae populations, especially in Ipono and Nkolondom.

Evidence of a strong correlation between resistance phenotype and $k d r$ genotypes has been documented in previous studies $[28,29]$. However, results provided in this study, agree with the standpoint suggested by Brooke [50], arguing that $k d r$ may act with certain co-factors that are thus far unidentified. This resistance mechanism could be multigenic, and the $k d r$ genotype might not fully explain all the variance in the resistance phenotype [51]. However, this hypothesis does not rule out the causal relationship between the $k d r$ genotype and susceptibility to DDT and pyrethroids [52].

The higher number of mutant homozygotes L1014F recorded in dead mosquitoes when exposed to $0.05 \%$ deltamethrin demonstrates that, $k d r$ may be less efficient in providing resistance to deltamethrin than it is for DDT and permethrin resistance, as previously suggested
$[37,53,54]$. Alternatively, the diagnostic dosage of deltamethrin may be very high and therefore killing resistant mosquitoes. Furthermore, other resistance mechanisms such as elevated oxidase, esterase or glutathione S-transferase activity may add to the $k d r$ effect and increase resistance to DDT and permethrin in Ipono. Metabolic resistance has already been reported in An. gambiae and An. arabiensis populations from Cameroon [25,35,55], although specific analysis were not carried out to explore these mechanisms within each molecular form. Meanwhile, resistance levels such as that reported here seem to be strongly associated with the $\mathrm{S}$ molecular form. However, attention must also be paid to the $\mathrm{M}$ molecular form considering the increasing frequency of the L1014F $k d r$ allele in this form [49].

The rise in frequency of both $k d r$ mutations in An. gambiae is probably facilitated by the intensive use of the same insecticides in agriculture, wood industry and public health, resulting in ubiquitously high selection pressure for resistance in insects [56]. Reports from Cameroon as well as other African countries have mentioned the rela- 
Table 3: Variations in molecular forms and kdr-alleles frequencies in tested Anopheles gambiae populations.

\begin{tabular}{|c|c|c|c|c|c|}
\hline An. gambiae & Site & Year & $\mathbf{N}(\%)$ & $f(L|0| 4 S)$ & $f(L|0| 4 F)$ \\
\hline \multirow[t]{12}{*}{ M-form } & Ipono & 2003 & $16(33)$ & ND & 0 \\
\hline & & 2005 & $22(61)$ & 0 & 0 \\
\hline & & 2007 & $19(30)$ & 0 & 0.10 \\
\hline & Nkolondom & 2003 & $26(60)$ & ND & 0 \\
\hline & & 2005 & $0(0)$ & - & - \\
\hline & & 2007 & $2(4)$ & 0 & $0.50 *$ \\
\hline & Mangoum & 2003 & $0(0)$ & - & - \\
\hline & & 2005 & $0(0)$ & - & - \\
\hline & & 2007 & $0(0)$ & - & - \\
\hline & Bonanloka & 2001 & $30(100)$ & ND & 0 \\
\hline & & 2005 & $33(63)$ & 0 & 0 \\
\hline & & 2007 & $33(58)$ & 0 & 0.18 \\
\hline \multirow[t]{12}{*}{ S-form } & Ipono & 2003 & $32(67)$ & ND & 0.04 \\
\hline & & 2005 & $14(39)$ & 0.03 & 0.25 \\
\hline & & 2007 & $45(70)$ & 0.18 & 0.62 \\
\hline & Nkolondom & 2003 & $17(39)$ & ND & 0 \\
\hline & & 2005 & $64(100)$ & 0.03 & 0.59 \\
\hline & & 2007 & $45(96)$ & 0.02 & 0.92 \\
\hline & Mangoum & 2003 & $51(100)$ & ND & 0.37 \\
\hline & & 2005 & $76(100)$ & 0.14 & 0.85 \\
\hline & & 2007 & $33(100)$ & 0.24 & 0.72 \\
\hline & Bonanloka & 2001 & $0(0)$ & - & ND \\
\hline & & 2005 & $19(37)$ & 0 & 0.20 \\
\hline & & 2007 & $24(42)$ & 0 & 0.16 \\
\hline
\end{tabular}

$\mathrm{N}$ : sample size; $\mathrm{f}()$ : frequency of the $k d r$ alleles; *: I specimen out of the 2 tested carried the mutation; ND: not determined.

Table 4: Phenotypes and genotypes at codon 1014 of the vgsc of Anopheles.gambiae collected in Ipono (December 2007).

\begin{tabular}{|c|c|c|c|c|c|c|c|c|c|c|c|}
\hline \multirow[t]{2}{*}{ Molecular form } & \multirow[t]{2}{*}{ Phenotype } & \multirow[t]{2}{*}{ Insecticide } & \multirow[t]{2}{*}{$\mathbf{N}$} & \multicolumn{6}{|c|}{ Genotypes } & \multirow[t]{2}{*}{ f(Ser) } & \multirow[t]{2}{*}{ f(Phe) } \\
\hline & & & & Leu-Leu & Leu-Phe & Leu-Ser & Ser-Ser & Phe-Phe & Phe-Ser & & \\
\hline \multirow[t]{7}{*}{ M-form } & Control & - & 19 & 15 & 4 & 0 & 0 & 0 & 0 & 0 & 0.10 \\
\hline & Dead & 4\%DDT & 8 & 6 & 2 & 0 & 0 & 0 & 0 & 0 & 0.12 \\
\hline & & 0.05\%Deltamethrin & 6 & 6 & 0 & 0 & 0 & 0 & 0 & 0 & 0 \\
\hline & & 0.75\%Permethrin & 13 & 8 & 2 & 0 & 0 & 3 & 0 & 0 & 0.31 \\
\hline & Survivor & $4 \% \mathrm{DDT}$ & 0 & - & - & - & - & - & - & - & - \\
\hline & & 0.05\%Deltamethrin & 0 & - & - & - & - & - & - & - & - \\
\hline & & $0.75 \%$ Permethrin & 0 & - & - & - & - & - & - & - & - \\
\hline \multirow[t]{7}{*}{ S-form } & Control & - & 45 & 4 & 7 & 2 & 3 & 20 & 9 & 0.18 & 0.62 \\
\hline & Dead & $4 \% \mathrm{DDT}$ & 11 & 2 & 4 & 3 & 0 & 1 & 1 & 0.18 & 0.41 \\
\hline & & 0.05\%Deltamethrin & 29 & 2 & 3 & 3 & 2 & 18 & I & 0.14 & 0.69 \\
\hline & & 0.75\%Permethrin & 15 & 2 & 4 & 1 & I & 4 & 3 & 0.20 & 0.50 \\
\hline & Survivor & $4 \% \mathrm{DDT}$ & 29 & 0 & I & 0 & 0 & 27 & 1 & 0.01 & 0.96 \\
\hline & & 0.05\%Deltamethrin & 6 & 0 & 0 & 0 & 0 & 3 & 3 & 0.25 & 0.75 \\
\hline & & $0.75 \%$ Permethrin & 33 & 0 & 0 & 0 & 0 & 24 & 9 & 0.14 & $0.86^{\prime}$ \\
\hline
\end{tabular}

$\mathrm{N}$ : sample size; $\mathrm{f}()$ : frequency of the resistant alleles $(\mathrm{LIOI} 4 \mathrm{~S}=\mathrm{Ser}$ and LIOI4F = Phe) in the mosquito pools; vgsc: voltage gated sodium channel 
tion between public health or agricultural use of insecticides and the evolution of insecticide resistance in malaria vectors [34,55-57]. In addition to cotton or rice cultivation areas, market gardening areas, public health or personal protection, the current study put forward forest exploitation sites (timber yards) as potential zones of insecticide resistance emergence in An. gambiae.

This study further highlights the dynamics of An. gambiae susceptibility to insecticides in southern Cameroon. Biological, genetic and environmental factors may intervene in modulating susceptibility to insecticides.

\section{Conclusion}

This study underlines the variability in the resistance level of An. gambiae s.s from southern Cameroon to the firstline insecticides currently used for its control. The current distribution of $k d r$ mutations and ongoing trends for their geographical spread and rise in frequency need to be carefully considered. Such a situation is a real threat for malaria vector control strategies implemented in South Cameroon and calls for close collaboration between pestmanagement and vector control programmes towards the implementation of sustainable resistance management strategies.

\section{Competing interests}

The authors declare that they have no competing interests.

\section{Authors' contributions}

JE and FS conceive the study. JE, FS, RM, and PN designed the study protocol; JE, PN, MC, JCT, CKH and HPAA performed field work and bioassays; PN performed molecular analyses; PN and JE analyzed and interpreted the data; PN drafted the manuscript which was critically revised by JE, RM and FS. All the authors read and approved the final manuscript.

\section{Acknowledgements}

We wish to thank Léonard Enama Nga, Nicolas Enoga and the communities in our study sites for their help and collaboration in the fields.

Financial support was provided by UNICEF/UNDP/World Bank/WHO/ Special Programme for Research and Training in Tropical Diseases (TDR): Multilateral Initiative on Malaria grant N ${ }^{\circ}$ A 10625 and Re-entry Grant number $\mathrm{A} 4 \mathrm{I} 48 \mathrm{I}$ to J.E.

\section{References}

I. Gariou J, Mouchet J: Apparition d'une souche d'Anopheles gambiae résistante à la dieldrine dans la zone de campagne antipaludique du Sud-Cameroun. Bull Soc Path Exot 1961, 54:870-875.

2. Livadas G, Mouchet J, Gariou J, Chastang R: Peut-on envisager l'éradication du paludisme dans la region forestière du SudCameroun? Revista di Malariologia 1958, 37:229-256.

3. Trigg PI, Kondrachine V: Bull World Health Organisation 1998, 76:11-16.

4. Cavalié $P$, Mouchet J: Les campagnes expérimentales d'éradication du paludisme dans le Nord de la République du Cameroun. Med Trop 1962, 22:95-118.
5. Mittal PK, Adak T, Sharma VP: Acute toxicity of certain organochlorine, organophosphorus, synthetic pyrethroid and microbial insecticides to the mosquito fish Gambusia affinis (Baird and Girard). Indian J Malariol 1991, 28:167-70.

6. Zaim M, Aitio A, Nakashima N: Safety of pyrethroid-treated nets. Med Vet Entomol 2000, 14:1-5.

7. WHO: Global strategic framework for integrated vector management. WHO/CDS/CPE/PVC/2004.10. Geneva, Switzerland .

8. WHO: Malaria vector control and personal protection. WHO Technical Report Series N ${ }^{\circ} 9362006$.

9. Guillet P: La lutte antivectorielle. Bull Soc Pathol Exot 200I, 94(2 bis): $165-168$

10. Coleman M, Hemingway J: Insecticide resistance monitoring and evaluation in disease transmitting mosquitoes. J Pest $\mathrm{Scl}$ 2007, 32(2):69-76

II. Georghiou GP: "Managing Resistance to Agrochemicals: From Fundamental Research to Practical Strategies. Edited by: Green MB, Lebaron HM, Moberg WK. American Chemical Society; Washington; 1990:18-41.

12. Green MB, LeBaron HM, Moberg WK: Managing resistance to agrochemicals. ACS Symposium Series; Washington DC; 1990:3-16.

13. Hargreaves K, Koekemoer LL, Brooke BD, Hunt RH, Mthembu J, Coetzee M: Anopheles funestus resistant to pyrethroid insecticides in South Africa. Med Vet Entomol 2000, 1 4:1-9.

14. Kazachkova NI: Genotype analysis and studies of pyrethroid resistance of the oilseed rape (Brassica napus) insect pestpollen beetle (Meligethes aeneus). In Doctoral Thesis Swedish University of Agricultural Sciences, Sweden; 2007:56.

15. Ranjekar PK, Aparna P, Gupta VB, Raj JB, Ananda KP: Genetic engineering of crop plants for insect resistance. Current Science 2003, 84(3):32I-329.

16. N'Guessan R, Corbel V, Akogbéto M, Rowland M: Reduced efficacy of insecticide-treated nets and indoor residual sprying for malaria control in pyrethroid resistance area, Benin. Emerg Infect Dis 2007, 13:199-206.

17. Sachs J, Malaney P: The economic and social burden of malaria. Nature 2002, 41 5:680-685.

18. Oppenoorth FJ: Biochemistry and genetics of insecticide resistance. Comprehensive insect physiology. Pergamon, Oxford 1985:73I-773

19. Prapanthadara L, Hemingway J, Ketterman AJ: Partial purification and characterization of glutathione S-transferases involved in DDT resistance from the mosquito Anopheles gambiae. Pest Biochem Physiol 1993, 47:1 19-133.

20. Chandre F, Darriet F, Manguin S, Brengues C, Carnevale P, Guillet P: Pyrethroid cross-resistance spectrum among populations of Anopheles gambiae s.s from Côte d'Ivoire. J Am Mosq Control Ass 1999, 15:53-9.

21. Hemingway J, Hawkes NJ, Mc Carroll L, Ranson H: The molecular basis of insecticides resistance in mosquitoes. Insect Biochem Molec Biol 2004, 34:653-65.

22. Poirié M, Raymond M, Pasteur N: Identification of two distinct amplifications of the esterases B locus in Culex pipiens (L) Mosquitoes from Mediterranean countries. Biochem Genet 1992, 30:13-26.

23. Raymond M, Chevillon C, Guillemaud T, Leonormand T, Pasteur $\mathrm{N}$ : An overview of evolution of the overproduced esterases in the mosquito Culex pipiens. Philos Trans $R$ Soc London B Biol Sci 1998, 353:1707-17II.

24. Rooker S, Guillemaud T, Bergé J, Pasteur N, Raymond M: Co-amplification of esterases $A$ and $B$ genes as a single unit in Culex pipiens mosquitoes. Heredity 1996, 77:555-561.

25. Müller P, Chouaibou M, Pignatelli P, Etang J, Walker ED, Donnelly MJ, Simard F, Ranson H: Pyrethroid tolerance associated with elevated expression of antioxidants and agricultural practice in Anopheles arabiensis sampled from an area of cotton fields in Northern Cameroon. Mol Ecol 2008, I 7(4): I I 45-I I 55.

26. Müller P, Donnelly MJ, Ranson $\mathrm{H}$ : Transcription profiling of a recently colonized pyrethroid resistant Anopheles gambiae strain from Ghana. BMC Genomics 2007, 8:36.

27. Brogdon G, Mc Allister J: Insecticide resistance and vector control. Emerg Infect Dis 1998, 4:605-6I3.

28. Martinez-Torres D, Chandre F, Williamson MS, Darriet F, Bergé JB, Devonshire AL, Guillet P, Pasteur N, Pauron D: Molecular characterization of pyrethroid knockdown resistance $(k d r)$ in the 
major malaria vector Anopheles gambiae s.s. Insect Mol Biol 1998, 7:179-184.

29. Ranson H, Jensen B, Vulvule JM, Wang X, Hemingway J, Collins FH: Identification of a point mutation in the voltage-gated sodium channel gene of Kenyan Anopheles gambiae associated with resistance to DDT and pyrethroids. Insect Mol Biol 2000, 9:49|-497.

30. Walsh SB, Dolden TA, Moores GD, Kristensen M, Lewis T, Devonshire AL, Williamson SM: Identification and characterization of mutations in housefly (Musca domestica) acetylcholinesterase involved in insecticide resistance. Biochem J 200I, 359:175-181.

31. Weill M, Fort P, Berthomieu A, Dubois MP, Pasteur N, Raymond M: A novel acetylcholinesterase gene in mosquitoes codes for the insecticide target and is non-homologous to the ace gene in Drosophila. Proc $R$ Soc 2002, 269:2007-2016.

32. N'Guessan R, Darriet F, Guillet P, Carnevale P, Traoré-Lamizana $P$ Corbel V, Koffi AA, Chandre F: Resistance to carbosulfan in field populations of Anopheles gambiae from Côte d'Ivoire based on reduced sensitivity of acetylcholinesterase. Med Vet Ento$\mathrm{mol}$ 2003, I 7:19-25.

33. Djogbénou L, Dabiré R, Diabaté A, Kengne P, Akogbéto M, Hougard JM, Chandre F: Identification and geographic distribution of the Ace- $I^{R}$ mutation in the malaria vector Anopheles gambiae in South-Western Burkina Faso, West Africa. Am J Trop Med Hyg 2008, 78(2):298-302.

34. Etang J, Manga L, Chandre F, Guillet P, Fondjo E, Mimpfoundi R, Toto JC, Fontenille D: Insecticide susceptibility status of Anopheles gambiae s.l. (Diptera: Culicidae) in the Republic of Cameroon. J Med Entomol 2003, 40:49I-497.

35. Etang J, Manga L, Toto JC, Guillet P, Fondjo E, Chandre F: Spectrum of metabolic-based resistance to DDT and pyrethroids in Anopheles gambiae s.I populations from Cameroon. J Vect Ecol 2007, 32(I):123-133.

36. Etang J, Fondjo E, Chandre F, Brengues $C$, Nwane $P$, Chouaúbou M, Ndjemai $\mathrm{H}$, Simard F: First report of knockdown mutations in the malaria vector Anopheles gambiae from Cameroon. Am J Trop Med Hyg 2006, 74:795-797.

37. Reimer L, Fondjo E, Patchoké S, Diallo B, Lee Y, Arash NG, Ndjemai HM, Atangana J, Traoré SF, Lanzaro G, Cornel JA: Relationship between $k d r$ mutation and resistance to pyrethroid and DDT insecticides in natural populations of Anopheles gambiae. I Med Entomol 2008, 45(2):260-266.

38. Suchel JB: Les climats du Cameroun. Thèse de Doctorat d'Etat. Université de Bordeau III; 1987:II 86.

39. Gillies MT, De Meillon B: The anophelinae of Africa South of the Sahara. second edition. South African Institute of Medical Research, Johannesburg; 1968

40. Gillies MT, Coetzee M: Supplement. The anophelinae of Africa South of the Sahara. South African Institute of Medical Research, Johannesburg; 1987.

41. WHO: Test procedures for insecticide resistance monitoring in malaria Vectors. Bio-efficacy and Persistence of insecticides on treated surfaces. WHO/MAL/98., 12. Report of the WHO Informal Consultation, Geneva 1998:43.

42. Morlais I, Ponçon N, Simard F, Cohuet A, Fontenille D: Intraspecific nucleotide variant in Anopheles gambiae: new insights into biology of malaria vectors. Am J Trop Med Hyg 2004, $7 \mathrm{I}(6): 795-802$.

43. Fanello C, Santolamazza F, della Torré A: Simultaneous identification of species and molecular forms of the Anopheles gambiae complex by PCR-RFLP. Med Vet Entomol 2002, 16:46I-464.

44. Lynd A, Ranson H, McCall PJ, Randle NP, Black WC IV, Walker ED Donnelly MJ: A simplified high-throughput method for pyrethroid knockdown resistance (kdr) detection in Anopheles gambiae. Malaria J 2005, 4:16.

45. Finney D): Probit analysis. 3rd edition. Cambridge University Press; Cambridge; 1971.

46. Akogbéto MC, Djouaka R, Noukpo H: Utilisation des insecticides agricoles au Bénin. Bull Soc Pathol Exot 2005, 98(5):400-405.

47. Ndjemaï HNM, Patchoké S, Atangana J, Etang J, Simard F, Bilong Bilong CF, Reimer L, Cornel A, Lanzaro CG, Fondjo E: The distribution of insecticide resistance in Anopheles gambiae s.l populations from Cameroon: an update. Trans Roy Soc Trop Med Hyg 2008 in press.
48. Pinto J, Lynd A, Elissa N, Donnelly MJ, Costa C, Gentile G, Caccone A, Do Rosário VE: Co-occurrence of East and West African kdr mutations suggests high levels of resistance to pyrethroid insecticides in Anopheles gambiae from Libreville, Gabon. Med Vet Entomol 2006, 20:27-32.

49. Santolamazza F, Calzetta M, Etang J, Barrese E, Dia I, Caccone A, Donnelly MJ, Petrarca V, Simard F, Pinto J, della Torre A: Distribution of knockdown resistance mutations in Anopheles gambiae molecular forms in West and West-Central Africa. Malar J 2008, 7:74

50. Bass C, Nikou D, Donnelly MJ, Williamson MS, Ranson H, Ball A, Vontas J, Field LM: Detection of knockdown resistance $(\mathbf{k d r})$ mutations in Anopheles gambiae: a comparison of two new highthroughput assays with existing methods. Malaria J 2007, 6: III.

51. Brooke BD: Kdr: can a single mutation produce an entire insecticide resistance phenotype? Trans Roy Soc Trop Med Hyg 2008, 102:524-525

52. Donnelly MJ, Corbel V, Weetman D, Wilding CS, Williamson MS, Black WC IV: Does kdr genotype predict insecticide-resistance phenotype in mosquitoes. Trends in Parasitology 2009, 25(5):213-9.

53. Awolola TS, Oduola AO, Oyewole IO, Obansa JB, Amajoh CN, Koekemoer LL, Coetzee M: Dynamics of knockdown pyrethroid insecticide resistance alleles in a field population of Anopheles gambiae s.s in southwestern Nigeria. J Vect Borne 2007, 44: $181-188$

54. Abdalla H, Matambo TS, Koekemoer LL, Mnzava AP, Hunt RH, Coetzee M: Insecticide susceptibility and vector status of natural populations of Anopheles arabiensis from Sudan. Trans Roy Soc Trop Med Hyg 2008, 102:263-27I.

55. Himeidan YE, Chen H, Chandre F, Donnelly MJ, Yan G: Permethrin and DDT resistance in the malaria vector Anopheles arabiensis from Eastern Sudan. Am J Trop Med Hyg 2007, 77: 1066-1068.

56. Diabaté $A$, Baldet $T$, Chandre F, Akogbéto $M$, Guiguemde RT, Darriet F, Brengues C, Guillet P, Hemingway J, Graham JS, Hougard JM: The role of agricultural use of insecticides in resistance to pyrethroids in Anopheles gambiae s.l. in Burkina Faso. Am J Trop Med Hyg 2002, 67:617-622.

57. Chouaïbou M, Etang J, Brevault T, Nwane P, Hinzoumbé CK, Mimpfoundi $R$, Simard F: Dynamics of insecticide resistance in the malaria vector Anopheles gambiae s.I from an area of extensive cotton cultivation in Northern Cameroon. Trop Med Int Hlth 2008, 13(4): I-II.

\section{Pre-publication history}

The pre-publication history for this paper can be accessed here:

http://www.biomedcentral.com/1471-2334/9/163/prepub

Publish with Biomed Central and every scientist can read your work free of charge

"BioMed Central will be the most significant development for disseminating the results of biomedical research in our lifetime."

Sir Paul Nurse, Cancer Research UK

Your research papers will be:

- available free of charge to the entire biomedical community

- peer reviewed and published immediately upon acceptance

- cited in PubMed and archived on PubMed Central

- yours - you keep the copyright
BioMedcentral 